\title{
Visual Identity and Packaging of Dairy Products From Small and Medium Enterprises
}

\author{
Mohamad Tohir ${ }^{1}$, Didit Widiatmoko Soewardikoen ${ }^{2}$ \\ ${ }^{1}$ DKV Telkom University, Bandung, Indonesia \\ ${ }^{2}$ DKV Telkom University, Bandung, Indonesia
}

mt.fauzy@gmail.com (Mohamad Tohir),widiatmokodw@gmail.com (Didit Widiatmoko Soewardikoen)

\begin{abstract}
Small and medium enterprises are one of the most significant and dominant drivers of the economy as producers of gross domestic product, in addition to absorbing the largest employment in some areas. Processed milk products of small and medium enterprises in Jatinangor as healthy drinks have a good chance to be marketed into prestigious beverages. The problem is the small to medium-sized businesses don't realize the importance of identity for a product, naming with a rather difficult pronunciation and difficult to remember, a less attractive logo makes this product less competitive with large-scale factory products. Through field observation, literature study, and interviews both to producers and to consumers are obtained the necessary data as the basis for the design identity of small and medium business brand of dairy products. Brand identity and its application to packaging design can make dairy products easily recognized by the public. This study aims to assist small and medium enterprises; especially processed milk maker in Jatinangor, Sumedang district, through product identity design marketing problems of small and medium business products can be helped.
\end{abstract}

Keywords Visual Identity, Yoghurt, Small Medium Entreprises

\section{Introduction}

SMEs is a strong enough business to survive during the economic crisis in Indonesia in processed products 1998. Contribution of Small and Medium Enterprises in addition to providing the most jobs, in some areas to be one of the driving forces of the economy is high enough, the dominant influence on the Gross Domestic Product. Small and Medium Enterprises will continue to be the government's attention as it will become the backbone of the Indonesian economy in the future. The Deputy Minister of Trade said that if Small and Medium Enterprises become the backbone of national income and as a provider of employment, the development policy in the sector of Small and Medium Enterprises is also needed to become a sector that encourages balanced and inclusive sustainable economic growth.

The problem that is often expressed by Small and Medium Enterprises is marketing. More specifically from these marketing issues related to the field of Visual Communication Design, is the identity problem or Brand identity and its application to the packaging. In the vicinity of Bandung there are several centers of cattle ranchers, one of them in Jatinangor Sumedang district. Cow's milk from farmers 'breeders is mostly absorbed by farmers' cooperatives which are then deposited to UHT (Ultra High Temperature) dairy producers and partly processed by farmers into ready-to-drink dairy products.
From dairy products, the farmers in Jatinangor market their products directly to consumers, dairy products are quite popular, but the availability of many dairy products ready to drink products on the market today certainly makes the competition between similar products to be higher, to be a product the choice of society requires an identity. The problem is that managers have not realized the importance of a brand as a product identity that should be easily remembered by consumers

\section{Theoretical Review}

Brand or brand is any name, term, sign, symbol, design or combination of all intended to identify the goods and services of a sale or group of sellers and to distinguish them from competitors' products or services (AMA in Swasty 2016: 4). Brand is a marker of a product or service consisting of verbal elements (name, tagline, and jingle) or Visual element (logo, mascot, and packaging) that distinguish a product or service with its competitors.

Furthermore, Sonsino explains that graphic design for packaging should project a message from the essence of a marketing process, and the most important thing is to pay attention to color, eye tracking, shape, size, typography, face display, and photography (1990: 50). Likewise, the colors that differentiate the personality, attract attention to other attributes, and make it possible to make a difference from competitors in the retail environment. The use of the right colors, can break through product categories and 
differentiate in a product line (Klimchuk and Krasovec, 2006: 107). Typography as the main medium for communicating the names, functions, and facts of the product to the widespread consumer. Typography selection, layout, and application of letters and word selection will affect how messages are read (Klimchuk and Krasovec, 2006: 87).

From the above definition it can be assumed that the brand is a feature of a product consisting of verbal elements and visual elements that distinguish a product with its competitors with the implementation on the packaging that has the structure and supporting material, graphic design that projects the marketing message, through the selection of colours and typography which are interesting. Processed dairy products from some of the Small and Medium Enterprises that produce yogurt have started to use good names, but the design and packaging used are still simple. When processed dairy products of Small Medium Enterprises can be made attractive brands and packaging can compete with dairy products in the supermarket.

\section{Methods}

Sampling, taken on the basis of the criteria for drinking milk produced by Small Medium Enterprises sold in small shops around residential areas, is sold in schools / campuses, and sold at events / bazaars held in various places, as well as comparing with packaging processed milk sold in upscale supermarkets. The study was conducted in Bandung.

The data collection is taken through observation instrument, observation and recording of selected visual samples according to the criteria, that is packaging of processed milk drink of SMALL BUSINESS MEDICINE products, also to packing milk products. Literature study, conducted on textbooks and e-books to obtain theories as a tool of analysis, and conducted on mass media and social media to get news and opinions on policies and developments of Small and Medium Enterprises, strengthen the perspective and put in context. The theories used to analyze are derived from the thinking of experts who have done the research. Theories are written based on a particular worldview or understanding that may occasionally be different from that of another expert (Soewardikoen, 2013: 6).

The conclusions drawn from the observations, interviews and literature studies that have been processed through matrix analysis in accordance with the question of research, in accordance with Soewardikoen opinion (2013: 50)., "Withdrawal conclusions can be made in generalization, withdrawal conclusions are considered convincing. Can also doing by way of conclusion from one or several facts. Formulate concepts, propositions, and theoretical after the results of research"

\section{Result and Discussion}

This study describes the types of dairy products produced, how dairy producers Small Medium Enterprises, choose packaging, and how marketing activities undertaken so far. To further this research can be developed for the manufacture of prototype packaging suitable for packaging of dairy products production of Small and Medium Enterprises.
In Jatinangor and Cipageran villages, raw materials of cow's milk have great potential as the income of farmers. Based on data collection, in one day the residents' dairy cows can produce 2,500 litres of milk. However, so far the local farmers directly sell the milk without processing even the slightest so as not to get the added value generated from the sale. Milk produced only sold to cooperatives and middlemen at Rp 4,300 per litres (data of August 2016). So farmers do not earn enough to support their lives, whereas, "Cow's milk processing can turn the milk raw material into high value-added products like yogurt, ice cream, milk tofu, milk crackers, candies, smoothies and more Again "(Saleh, 2004).

Processing milk dairy into yogurt products is one of the most enabling alternatives as the beginning of efforts to improve the welfare of the local community, related to its ability to extend shelf life, as well as "a healthy food product where the manufacture of yogurt using bacteria Lactobacillus bulgaricus and Streptococcus thermophilus which Fermented "(Saleh, 2004). Yogurt products have high health benefits including medicinal value of stomach and intestinal tract, lowering cholesterol in blood, high protein content, and low fat content.

The idea of adding value to milk dairy products in Jatinangor was initiated by a group of UNPAD agricultural engineering students who did field practice, they tried to process milk breeders into yogurt which later developed into Small Medium Enterprises using the brand 'Yourgood'. These yogurt is packaged in $100 \mathrm{ml}$ plastic bottles. And 250 $\mathrm{ml}$, with various flavors of melon, strowberry, grape, green tea, and mocha. This product is sold in a limited circle such as restaurants, cafes, and individual consumers for reasons of production capacity is still limited and the price is relatively more expensive but has a fairly good quality compared with similar products circulating in the market.

Based on the interview with Br. Rizal Arafat (founder of YourGood), that they have a desire to develop the market along with the addition of production capacity as more and more breeders who want to join this Small Medium Enterprises, so that there needs to be development in terms of packaging and visual appearance of YourGood products, the picture below is Examples of products already sold:

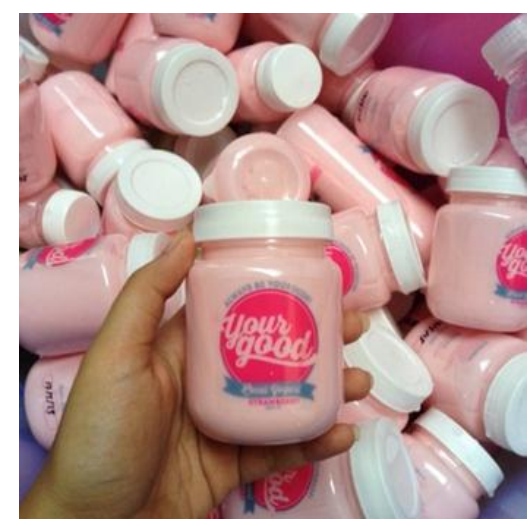

Figure 1. YourGood's packaging

The naming of Yourgood itself is chosen to have high selling value, in accordance with morph sociolinguistic science, this naming resulted from the collaboration between 
Yourgood team with the Faculty of Cultural Sciences (FIB-UNPAD) as the competent party in the field of linguistics. The name Yourgood consists of the words "Your" and "Good" which means that Yourgood is a product that provides and stores goodness. In addition, Yourgood pronunciation is not difficult and easy enough to remember because the pronunciation is similar to yogurt so the community is easy to associate the name with the product.

For comparison of samples of similar products taken from supermarkets / minimarkets in Bandung, there are two visually prominent brands displayed on refrigerator shelves in supermarkets / minimarket, the Cimory and Heavenly blush brands, as seen in picture below:
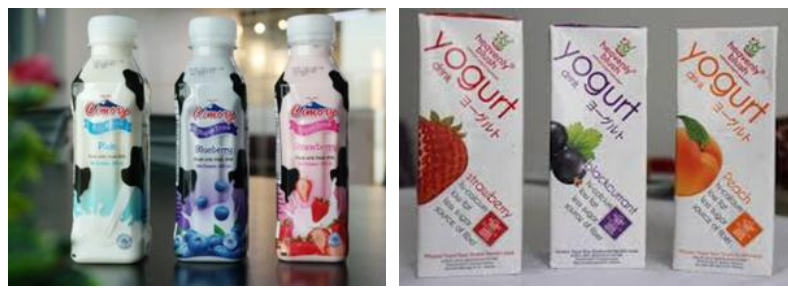

Figure 2. Cimory and Heavenly blush packaging

Yogurt products are quite popular among students and people who live a healthy lifestyle in the city of Bandung. In addition to drink directly yogurt can be mixed with fresh fruits and ice cream as a variation of dessert.

\subsection{Processed Milk Packaging Small and Medium Busi- ness Products}

Transparent plastic bottle packaging is thick enough to make the price more expensive, especially if the purchase of packaging is done in a small party; Yourgood brand is made in a negative and transparent print make the color change according to the color of the flavor / contents in the bottle; Dynamic and minimalist layout makes this product visible enough if it's in the same product group; There are two colors that are used to suit the taste, this makes the color inconsistency on the look of Yourgood brand; Typography used is a modified script letters; No illustrations or product information makes consumers hesitant to choose this product.

Tetra pack packaging has a more expensive price than plastic bottle packaging in addition to require high technology, but for large capital producers it is not a problem because it is an investment that must be spent to support marketing; The Heavenly blush brand is printed in smaller letters of yogurt writing, this is intended to inform the consumer of the products contained in the pack as a priority compared to that brand; Diagonal layout with the addition of more than 3 visual elements to be differentiated from the appearance of similar products; Full color printed packaging with white base displaying excellent contrast, font color and illustrations adjust to taste but Heavenly blush writing still uses red in every packaging variant, this shows the consistency of trademark display; Typography used is the type Arial san-serif letter combined with the kanji that suggests that Heavenly blush is an imported product; There are illustra- tions as well as product information making consumers no doubt to choose this product

The thin plastic bottle packaging has a lower price than the previous two product packs, for large capital producers it is profitable because the purchase of large quantities of packaging can reduce the cost of production, this will affect the selling price; Cimory brand printed using modified script letters; centered layout with the addition of more than 3 visually visible visual elements; Full color printed packaging with transparent base, font color and illustration adjusting to taste but Cimory writing still use red in every packaging variant, this shows the consistency of trademark display; Typography used more than 3 types of letters that is script, serif and san-serif; There are illustrations as well as product information, this condition causes unclear focus of the view because overall looks solid.

\section{Conclusion}

In making the packaging, Small Medium Enterprise dairy products already have awareness of Brand, business owners to name dairy products with names that associate good values. Using sub headline and tagline that expressed the difference and quality. Color selection for the brand has not displayed contrast, with products packed with clear ingredients that the product name changes color according to the color of the content / flavor, causing brand inconsistency. Typographic selection using script letters is still not appropriate because the level of legibility is rather difficult. Using centered layout Inadequacy of other attributes in packaging such as product information, BPOM permits and expiration dates cause the level of consumer confidence to decrease. The thick plastic bottle packaging purchased in small party results in a high enough prices and manually printed high selling prices thereby reducing competitiveness in marketing. While the dairy products of large capital businesses already use layouts, fonts and colors are more regular, as well as the selection of brand names and visual elements. In terms of packaging material selection, large capital products are able to purchase large quantities of packaging and invest capital in the form of packaging machines with high-quality prints so that the packaging looks better and neatly

\section{ACKNOWLEDGEMENT(S)}

Rizal Arafat, founder of YourGood Small Medium Enterprises.

\section{REFERENCES}

[1] S. M. Metev and V. P. Veiko, Laser Assisted Microtechnology, 2nd ed., R. M. Osgood, Jr., Ed. Berlin, Germany: Springer-Verlag, 1998. 
[2] J. Breckling, Ed., The Analysis of Directional Time Series: Applications to Wind Speed and Direction, ser. Lecture Notes in Statistics. Berlin, Germany: Springer, 1989, vol. 61.

[3] S. Zhang, C. Zhu, J. K. O. Sin, and P. K. T. Mok, "A novel ultrathin elevated channel low-temperature poly-Si TFT," IEEE Electron Device Lett., vol. 20, pp. 569-571, Nov. 1999.

[4] M. Wegmuller, J. P. von der Weid, P. Oberson, and N. Gisin, "High resolution fiber distributed measurements with coherent OFDR," in Proc. ECOC'00, 2000, paper 11.3.4, p. 109.

[5] R. E. Sorace, V. S. Reinhardt, and S. A. Vaughn, "High-speed digital-to-RF converter," U.S. Patent 5668 842, Sept. 16, 1997.

[6] M. Shell. (2002) IEEEtran homepage on CTAN. [Online]. Available: http://www.ctan.org/tex-archive/macros/latex/contrib/suppor ted/IEEEtran/

[7] FLEXChip Signal Processor (MC68175/D), Motorola, 1996.

[8] "PDCA12-70 data sheet," Opto Speed SA, Mezzovico, Switzerland.

[9] A. Karnik, "Performance of TCP congestion control with rate feedback: TCP/ABR and rate adaptive TCP/IP," M. Eng. thesis, Indian Institute of Science, Bangalore, India, Jan. 1999.

[10] J. Padhye, V. Firoiu, and D. Towsley, "A stochastic model of TCP Reno congestion avoidance and control," Univ. of Massachusetts, Amherst, MA, CMPSCI Tech. Rep. 99-02, 1999

[11] Matlock, H., and Reese, L.C., 1960, Generalized solutions for laterally loaded piles., Journal of Soil Mechanics and Foundation, 86(5), 63-91.

[12] Nayak, G. C., and Zienkiewicz, O. C., 1972, Convenient forms of stress invariants for plasticity, Proc. ASCE, 98(4), 949-953.

[13] Noorzaei, J., Viladkar, M. N., Godbole, P. N., 1995, Influence of strain hardening on soil-structure interaction of framed structures, Computers \& Structures, 55(5), 789-795.

[14] Owen, D. R. J., and Hinton, E., 1980, Finite elements in plasticity-theory and practice, Pineridge Press, Swansea.

[15] Pise, P. J., 1982, Laterally loaded piles in a two-layer soil system., J. Geotech. Engrg. Div., 108(9), 1177-1181.

[16] Poulos, H. G., 1971, Behavior of laterally loaded piles-I: Single piles., J. Soil Mech. and Found. Div., 97(5), 711-731.

[17] Reese, L. C., and Matlock, H., 1956, Non-dimensional solutions for laterally loaded piles with soil modulus assumed proportional to depth., Proc., 8th Texas Conf. on Soil Mechanics and Foundation Engineering, Austin, Texas, 1-23

[18] Reese, L. C., and Welch, R. C., 1975, Lateral loading of deep foundations in stiff clay., J. Geotech. Engrg. Div., 101(7), 633-649.

[19] Ambrose, Gavin; Harris, Paul (2011): Packaging the Brand. Switzerland: AVA Publishing SA.

[20] Klimchuk, Marianne R. \& Krasovec, Sandra A (2007): Desain Kemasan: Perencanaan Merek Produk yang Berhasil Mulai dari Konsep sampai Penjualan. Jakarta: Erlangga.

[21] Soewardikoen, D. Widiatmoko., (2013): Metodologi Penelitian Visual. Bandung. PT Dinamika Komunika.
[22] Sonsino, Steven., (1990): Packaging Design. UK: Thames and Hudson.

[23] Widiatmoko, Didit, (2007): Menghidangkan Esensi Kemasan. Jakarta: Majalah Concept Vol. 3 Halaman 18.

[24] Kemendag: USAHA KECIL MENENGAH (http://beritadaerah.co.id/2014/10/02/kemendag usaha kecil menengah-sebagai tulang punggung ekonomi semua negara)

[25] Nashrullah Hasin, 2015, Era Membranding Produk UMKM (http://kemasanukm) 